Ewa Hyży

Uniwersytet Medyczny w Łodzi

\title{
Prawa kobiet jako prawa człowieka
}

\begin{abstract}
$\mathrm{O}$ d kilku dekad słychać głosy obwieszczające zmierzch feminizmu zarówno jako progresywnego projektu politycznego, jak i dyscypliny teoretycznej. Ogłoszona została era postfeminizmu, co powszechnie rozumiane jest jako wyczerpanie się feminizmu jako ruchu; spełniwszy swoją rolę, przeszedł on do historii. Stwierdza się, że okres masowych ruchów społecznych już minął. Zapotrzebowanie na dane przedsięwzięcie pojawia się w kontekście określonej sytuacji społeczno-politycznej, co powoduje niezbędne i nieuniknione zmiany w sferze strategii działań grup społecznych. Wykorzystuje się bardziej adekwatne środki protestów i narzędzia prowadzące do zmian kwestionowanego porządku. Nie istnieją już ruchy w takich formach, jakie przybierały w latach siedemdziesiątych i osiemdziesiątych XX wieku. Dotyczy to również ruchu feministycznego, który przyjął inne sposoby działania, zajmuje inne pozycje i tworzy nowe propozycje teoretyczne. Niemniej jednak tak długo, jak istnieją przejawy nierówności i niesprawiedliwości społecznej (w tym głównie genderowej) jest on ważny i potrzebny.

Jakie są zatem współczesne programy feminizmu(ów)? Czym zajmują się teoretyczki i praktyczki międzynarodowych feministycznych projektów? Podstawowym zadaniem środowisk feministycznych jest obecnie poszukiwanie odpowiedzi na postępującą globalizację i jej konsekwencje oraz troska o zachowanie transformacyjnego i emancypacyjnego charakteru feminizmu(ów), jak również aktywne uczestnictwo w procesie pożądanych zmian społecznych. Analizując wybrane przykłady teoretycznych propozycji feministycznych, reprezentowanych przez Niamh Reilly, Carol C. Gould i Brooke A. Ackerly, w swoim artykule zwracam uwagę na feministyczną krytykę ogólnej teorii praw człowieka i na projekt wyodrębnienia praw kobiet jako praw człowieka (women's human rights). Biorę pod uwagę dopełniające się perspektywy: historyczno-polityczną, filozoficzno-etyczną i metodologiczno-praktyczną.
\end{abstract}




\section{Prawa kobiet jako prawa człowieka}

Prawa człowieka sformułowane zostały jako projekt o charakterze uniwersalnym, dotyczącym wszystkich ludzi. W związku z tym rodzą się dwa podstawowe pytania. Po pierwsze, jak pogodzić uniwersalizm praw człowieka ze zróżnicowaniem wynikającym z podziału na płeć? Po drugie, jak uzgodnić koncepcję praw uniwersalnych z feministycznym skupieniem na różnicy, odmienności i lokalności? Czy nie mamy tu do czynienia z nierozwiązywalnymi paradoksami?

Koncepcja praw kobiet jako praw człowieka zawdzięcza swoje pojawienie się i realizację wytężonej działalności feministek z całego świata. Charlotte Bunch, słynna amerykańska aktywistka i jedna z głównych przedstawicielek tej inicjatywy, sformułowanie samej frazy przypisuje koalicji kobiet utworzonej w 1984 roku przeciwko reżimowi Ferdinanda Markosa na Filippinach - GABRIELA (General Assembly Binding Women for Reforms, Integrity, Equality, Leadership, and Action) ${ }^{1}$. Podmiotowość kobiet w zakresie powszechnych praw człowieka mogłaby wydawać się oczywista i niewymagająca dalszych uściśleń. W praktyce wprowadzenie kategorii praw kobiet okazało się jednak koniecznym przedsięwzięciem. Powszechna deklaracja praw człowieka, przyjęta przez Zgromadzenie Ogólne ONZ w 1948 roku, ustanawia to, co uważa się za fundamentalny konsensus w kwestii praw, zwłaszcza w relacji do takich zagadnień, jak: bezpieczeństwo, swoboda poruszania się, wolność słowa, religii, zrzeszania, zakaz niewolnictwa i tortur. Deklaracja obejmuje wszystkich ludzi, jednakże stereotypy, tradycje, normy społeczne, przesądy, interesy ekonomiczne i ubóstwo praktycznie wykluczały dotąd kobiety, relegując je do podrzędnej kategorii.

Głównym czynnikiem marginalizacji kobiet w międzynarodowych mechanizmach funkcjonowania praw człowieka był przyjęty przez tradycyjny liberalizm podział na sferę prywatną i publiczną. Jako źródło utrzymywania się tego podziału można wskazać potrzebę ochrony życia prywatnego, głównie poprzez ograniczanie rządowej jurysdykcji do sfery publicznej. Powszechna deklaracja praw człowieka regulowała więc przede wszystkim interakcje pomiędzy państwem, jego instytucjami i obywatelami. Głównym obszarem zainteresowania międzynarodowych instytucji stojących na straży przestrzegania praw były przypadki naruszeń w obrębie tych interakcji. Status obywatela w różnych krajach jednakże bywa często wyłączający, ograniczający lub wzmacniający daną grupę. Do osób uprzywilejowanych, które dominują w sferze publicznej i w kręgach rządowych, należą zazwyczaj

${ }^{1}$ Akronim GABRIELA wybrany został ze względu na pamięć filipińskiej rewolucjonistki z okresu walki przeciw Hiszpanom. Por.: Charlotte Bunch, Women's Human Rights: From Slogan to Global Agenda; dostępne przez: http://womensenews.org/story/books/120309/ womens-human-rights-slogan-global-agenda (01.05.2013). 
mężczyźni. Kobiety tymczasem mogły odwoływać się do międzynarodowych instytucji ochrony praw człowieka, ale niektóre z ich płciowo uwarunkowanych doświadczeń (np. gwałty w czasie uwięzienia czy podczas konfliktów zbrojnych) nie były klasyfikowane jako wymagające odrębnej uwagi. Natomiast naruszenia praw człowieka wobec kobiet zachodzące w sferze prywatnej w ogóle nie były dostrzegane. Przemoc doświadczana przez kobiety $\mathrm{z}$ rąk mężczyzn, przemoc domowa, często dokonywana w imieniu rodziny, religii czy kultury, była pomijana (mimo istnienia państwowych regulacji prawnych) lub nie była efektywnie ścigana przez instytucje państwowe, pozostawiając sprawców bezkarnymi.

Podział na sfery prywatną i publiczną stanowił zasadniczą, ale nie jedyną przeszkodę w ochronie kobiet. Po II wojnie światowej organizacje ONZ zajmujące się monitorowaniem przestrzegania praw człowieka interesowały się głównie czuwaniem nad respektowaniem praw obywatelskich i politycznych celem umocnienia ustrojów demokratycznych. W okresie zimnej wojny i rozwoju kapitalizmu prawa te stały się priorytetem z uwagi na rolę, jaką odgrywały w gospodarce wolnorynkowej. Wszystko to powodowało, że kobiety, nie dysponując odpowiednimi społecznymi i ekonomicznymi warunkami oraz nie mogąc w pełni partycypować w życiu publicznym (lub kiedy ich udział był znacznie ograniczony), nie były w stanie realizować swoich praw człowieka.

\section{Wydarzenia i dokumenty}

Z końcem lat sześćdziesiątych XX wieku pod wpływem aktywności działaczek drugiej fali sytuacja zaczęła ulegać istotnym zmianom. Feministki doprowadziły do tego, że Zgromadzenie Generalne ONZ ustanowiło rok 1975 Międzynarodowym Rokiem Kobiet, zorganizowało w stolicy Meksyku I Światową Konferencję Kobiet i, odpowiadając na postulaty uczestniczek tej konferencji, ogłosiło lata 1976-1985 Dekadą Kobiet. Następne sponsorowane przez ONZ konferencje odbywały się kolejno w Kopenhadze (1980) i Nairobi (1985); ta ostatnia często uznawana jest za moment narodziny globalnego feminizmu. W strukturach ONZ zaczęły również powstawać organizacje, w których kobiety uczyły się współpracować i tworzyć strategie dla poprawy swojej lokalnej i globalnej pozycji społecznej. Na początku lat dziewięćdziesiątych feministki podjęły również refleksję teoretyczną na temat praw człowieka, tworzyły programy i wskazówki dla działalności aktywistek. Jednocześnie wykazały, że dotychczasowe praktyki ochrony praw człowieka nie zdawały egzaminu w przypadku kobiet, gdyż nie uwzględniały zróżnicowania płci.

Dokumentem wyznaczającym standardy ochrony praw kobiet miała być Konwencja w sprawie likwidacji wszelkich form dyskryminacji kobiet 
(CEDAW) z 1979 roku $^{2}$, ratyfikowana przez 186 państw. Jej przestrzeganie jest monitorowane przez założony w 1981 roku Komitet ds. Likwidacji Dyskryminacji Kobiet, który, na podstawie rządowych i pozarządowych sprawozdań organizacji odpowiedzialnych za wcielanie w życie Konwencji, co cztery lata opracowuje odpowiednie raporty. Konwencja CEDAW okazała się jednak mało czy wręcz nieskuteczna w praktyce, zwłaszcza w kontekście innych regulacji o charakterze międzynarodowym. Przyczyną tego był brak wskazówek określających sposoby monitorowania jej uregulowań oraz relatywnie niezobowiązujący (w porównaniu z innymi traktatami dotyczącymi, na przykład, handlu i finansów) wymóg jej przestrzegania. Wszystko to uniemożliwiało Komitetowi CEDAW podejmowanie akcji własnych w przypadkach otrzymania informacji o naruszeniu prawa.

W pierwszej dekadzie swojego funkcjonowania Komitet był także, w porównaniu z innymi agencjami, niedofinansowany. Dopiero Konferencja w Wiedniu w 1993 roku, która zapoczątkowała międzynarodowy ruch na rzecz praw kobiet jako praw człowieka (Global Campaign) na nowo skierowała uwagę na CEDAW. Wiedeńska deklaracja i programy działania (poparte dokumentem z 2005 roku, cz. II, pkt. 3-4)3 oraz wydana przez Zgromadzenie Ogólne ONZ Deklaracja o likwidacji przemocy wobec kobiet z 1993 roku (art. 4) ${ }^{4}$ stwierdzają, że w przypadku konfliktu pomiędzy prawami kobiet a kulturowymi lub religijnymi praktykami, prawa kobiet muszą mieć priorytet. Przemoc wobec kobiet została tym samym uznana za naruszenie praw człowieka. Pojawiły się wówczas również nowe procedury skarg, między innymi dodatkowy protokół umożliwiający zgłaszanie przypadków naruszania praw w imieniu i za zgodą jednostek i grup. Fakultatywny protokół z 1997 roku dał Komitetowi CEDAW władzę inicjowania procesu badania naruszania praw kobiet ${ }^{5}$.

Duże znaczenie odegrała również przyjęta wcześniej Deklaracja o prawie do rozwoju (Declaration on the Right to Development, 1986). W artykule trzecim stanowi ona, że wszystkie prawa i podstawowe wolności człowieka są niepodzielne i wzajemnie od siebie zależne oraz że szczególnej uwagi i pilnego rozpatrzenia wymaga implementacja, promocja i ochrona praw

${ }^{2}$ Przed CEDAW wprowadzono Konwencję o prawach politycznych kobiet (1952), Konwencję o obywatelstwie kobiet zamężnych (1957) oraz Konwencję w sprawie zgody na zawarcie małżeństwa, najniższego wieku małżeńskiego i rejestracji małżeństw (1962).

3 Action Plan, Council of Europe, 17 May 2005; dostępne przez: http://www.coe.int/t/ dcr/summit/20050517_plan_action_pl.asp (01.05.2013).

4 Deklaracja o eliminacji przemocy wobec kobiet; dostępne przez: http://www.bezuprzedzen.org/doc/3cdeklPrzeciwPrzem.pdf (01.05 2013).

5 Jane Connor, Optional Protocol to the Convention on the Elimination of All Forms of Discrimination against Women; dostępne przez: http://untreaty.un.org/cod/avl/ha/ opceafdw/opceafdw.html (03.05 2013). 
gospodarczych, społecznych i kulturowych ${ }^{6}$. Ogłoszenie niepodzielności praw człowieka i podstawowych wolności zobowiązywało rządy do traktowania praw gospodarczych i społecznych na równi z prawami obywatelskimi i politycznymi. Zasada ta okazała się szczególnie istotna z perspektywy kobiet, ponieważ wyznaczała ramy umożliwiające podkreślenie złożoności problemów ich dotyczących oraz pozwalała domagać się, by ich pozycja polityczna nie była rozpoznawana w separacji od praw społecznych i ekonomicznych.

Najgłośniejszym jak dotąd wydarzeniem w sferze praw kobiet była mająca miejsce w Pekinie w 1995 roku IV Konferencja, która w całości została im poświecona. Uchwała tej konferencji stworzyła publiczne forum, na którym kobiety z całego świata mogły zacząć stawiać pytania dotyczące dyskryminacji i przemocy jakiej doświadczają w życiu codziennym i politycznym, w przypadkach spraw sądowych oraz w wysiłkach edukacyjnych.

Jak wiadomo, uzgodnienia, deklaracje i petycje ONZ nie mają siły wykonawczej i nie są prawnie obowiązujące, mają jednak polityczną i etyczną moc oraz mogą być pomocne dla rozstrzygania spraw wewnątrzpaństwowych i lokalnych. Stanowią także podstawę do wydawania i interpretacji międzynarodowych traktatów i konwencji. Te zaś - po podpisaniu przez rządy - jako mające status prawa międzynarodowego, uznawane są w sądach. Sprawy dotyczące tych zagadnień prowadzone są przez wyspecjalizowanych prawników. Ramy praw kobiet jako praw człowieka stworzyły więc przestrzeń, która dała kobietom z całego świata możliwość współpracy w kwestiach dotyczących ich problemów. Wypracowały też narzędzia do rozważania najważniejszych zagadnień z tego obszaru, uwzględniających specyficzne polityczne, geograficzne, ekonomiczne i kulturowe konteksty oraz dostarczyły słownictwa dla opisu doznawanej przez kobiety przemocy. Stały się wreszcie platformą do dzielenia się doświadczeniami z innymi kobietami, udostępniając alternatywne wizje stylów życia i, w konsekwencji, tworząc płaszczyznę dla łączenia wysiłków w celu dokonania oczekiwanych zmian.

Najświeższym dokumentem dotyczącym omawianych kwestii jest zainicjowana 11 maja 2011 roku w Stambule Konwencja o zapobieganiu i zwalczaniu przemocy wobec kobiet i przemocy domowej (CAHVIO), którą podpisało dotąd (kwiecień 2013 roku) 26 państw7.

Instytucja praw człowieka poddawana jest krytyce z różnych intelektualnych stanowisk: komunitariańskiego, kulturowych relatywistów, socjalistycznego czy postmodernistycznego. Każda pozycja przedstawia inne, oparte

${ }^{6}$ Declaration on the Right to Development, dostępne przez: http://www.un.org/documents/ga/res/41/a41r128.htm (03.05.2013).

7 Council of Europe Convention on Preventing and Combating Violence against Women and Domestic Violence; dostępne przez: http://conventions.coe.int/Treaty/Commun/ChercheSig.asp?NT=210\&CM=1\&DF=\&CL=ENG (03.05.2013). 
na charakterystycznym dla siebie punkcie widzenia, zastrzeżenia. W ramach feminizmu(ów) debata skupia się na rozważaniu, czy uniwersalizujące projekty, sformułowane w zgodzie z zachodnim modelem liberalnym, są w stanie uwzględnić różnorodność tożsamości i sytuacji kobiet. Pojawia się bowiem dylemat, czy poszukiwanie jakiegoś wspólnie podzielanego doświadczenia, podobnych interesów i celów kobiet z różnych części świata wspomaga emancypacyjną siłę feminizmu, czy może ją podważa. Innymi słowy, są to dyskusje na temat możliwości negocjowania w ramach projektów transnarodowych uniwersalnych postaw z równoczesnym zachowaniem różnic.

Pogłębiona krytyka dotycząca adekwatności ram praw człowieka dla polityki feministycznej nadeszła ze strony feministek postkolonialnych ${ }^{8}$. Podstawowe zarzuty podkreślały zachodniocentryczny charakter powyższych praw, z ich neoliberalną, męską (stronniczą) interpretacją, czyli kwestię „fałszywej uniwersalizacji”. Postkolonialne feministki uważają, że zachodnie normy narzucane są nie tylko krajom niezachodnim, ale również niedominującym grupom społecznym, takim jak kobiety, mniejszości seksualne i etniczne. Ich zastrzeżenia budzą również konsekwencje dominowania liberalnego indywidualizmu, uprzywilejowującego prawo własności prywatnej i prawa do profitu ponad prawami do rozwoju, zdrowia i ogólnego dobrostanu, oraz niedostrzeganie nierówności wynikających z nowopowstających globalnych struktur polityczno-ekonomicznych. Krytyka postkolonialna odegrała ważną rolę głównie dlatego, że sprowokowała zachodnie feministki, z jednej strony, do refleksji i ostrożności w proponowaniu rozwiązań, a z drugiej, do pogłębionej oceny i umocnienia swoich stanowisk.

\section{Niamh Reilly: feministyczna rehabilitacja praw człowieka}

Jedną z czołowych współczesnych feministycznych teoretyczek i adwokatek praw człowieka jest amerykańsko-irlandzka politolożka Niamh Reilly. Swoje stanowisko określa jako „emancypacyjny kosmopolityczny feminizm” (emancipatory cosmopolitan feminism). Oparty jest on na idei i praktyce praw człowieka, które mimo błędów i niepowodzeń nadal pozostają, jej zdaniem, nieodzownym punktem wyjścia dla podważania wszystkich form opresji i dyskryminacji w wymiarze globalnym. Reilly spędziła kilka lat, pracując w założonym przez Charlotte Bunch Center for Women's Global Leadership, w Rutgers University. Organizacja ta nie tylko odgrywa ważną rolę $\mathrm{w}$ promowaniu transnarodowego feministycznego zaangażowania

${ }^{8}$ Zob. chociażby: Chandra Talpade Mohanty, Under Western Eyes Feminist Scholarship and Colonial Discourses, „Feminist Review” 1988, no. 30, s. 65-88; Gayatri Chakravorty Spivak, Can the Subaltern Speak?, [w:] eds. Cary Nelson, Lawrence Grossberg, Marxism and the Interpretation of Culture, University of Illinois Press, Urbana (IL) 1988, s. 271-313. 
w prawa człowieka, ale również działa w ramach, przywołanego wcześniej, szerszego przedsięwzięcia koordynującego międzynarodowy ruch na rzecz praw kobiet Global Campaign, którego celem jest monitorowanie postępów ONZ i reprezentowanie praw kobiet na świecie9.

Niamh Reilly stoi na stanowisku, że krytyka jest wprawdzie niezbędnym instrumentem wszelkich zmian, jednakże winna być wspomagana również przez pozytywne projekty pokazujące funkcjonowanie instytucji praw człowieka jako emancypacyjnej praktyki politycznej. Formułując wskazówki dla rozwoju transnarodowego feminizmu, podkreśla potrzebę szerszego włączania się ruchu kobiet do pracy w pozarządowych i rządowych instytucjach, dla znoszenia prawnych i zwyczajowych ograniczeń wpływających upośledzająco na sytuację kobiet i dziewczyn ${ }^{10}$.

Odnosząc się do dokonanej przez przedstawicielki feminizmu postkolonialnego negatywnej oceny feministycznej ochrony praw człowieka (głównie tej w ramach projektów rządowych), Reilly uważa, że o ile niesprawiedliwe byłoby określanie całego zachodniego feministycznego aktywizmu z okresu późnych lat osiemdziesiątych i wczesnych dziewięćdziesiątych XX wieku mianem neoimperialnego, o tyle rzeczywiście nie brakowało w nim przykładów aroganckich wręcz interwencji zachodnich feministek, angażujących się w „ocalanie” kobiet z Trzeciego Świata przed „barbarzyńskimi praktykami”. Ewentualne błędy w interpretacji i aplikacji praw nie powinny być jednak postrzegane jako klęska modernistycznego paradygmatu praw człowieka. Należy raczej dokładnie określać sposoby ich skutecznego egzekwowania oraz wzmacniać ich transformującą rolę. Reilly przyjmuje tu stanowisko Umy Narayan ${ }^{11}$, że antyzachodnia antyuniwersalistyczna krytyka obecna $\mathrm{w}$ większości prac postkolonialnych może prowadzić do kulturowego esencjalizmu, stając się paradoksalnie niekorzystną dla interesów kobiet z krajów Trzeciego Świata. Istotne jest zatem dążenie do zachowania integralności feministycznych przedsięwzięć w oparciu o, jak to określa Chandra Talpade Mohanty, „wspólną różnicę”

Podważanie ustaleń, które prowadzą do nieefektywności oraz wykluczającego charakteru niektórych rozstrzygnięć instytucji praw człowieka może

9 Charlotte Bunch, Global Campaign for Women's Human Rights: Where Next After Vienna, „St. John's Law Review” 1995, vol. 69, issue 1, no. 1-2, s. 171-177. Obecnie Reilly jest jedną ze współdyrektorek tej organizacji.

${ }^{10}$ Niamh Reilly, Women's Human Rights: Seeking Gender Justice in a Globalizing Age, Polity Press, Cambridge 2009, s. 61.

${ }^{11}$ Uma Narayan, Essence of Culture and a Sense of History: A Feminist Critique of Cultural Essentialism, [w:] eds. Uma Narayan, Sandra Harding, Decentering the Center: Philosophy for Multicultural, Postcolonial and Feminist World, Indiana University Press, Bloomington 2000, s. 85 .

${ }^{12}$ ChandraTalpade Mohanty, op. cit., s. 224-226. 
być dokonane dzięki kontrhegemonicznemu podejściu, do którego Reilly zalicza zrewidowane projekty współczesnego transnarodowego feminizmu, jaki zresztą sama uprawia. Przepracowania, jej zdaniem, wymagają takie kwestie, jak: podział na sferę prywatną i publiczną, dominacja państwocentryczności, uniwersalność i westernizacja systemu praw człowieka ${ }^{13}$.

\section{a. Sfera prywatna i publiczna}

Podział na sferę publiczną i prywatną prowadzi do eliminowania z pola widzenia niektórych poważnych naruszeń prawa. Przed przyjęciem Rzymskiego Statutu Międzynarodowego Trybunału Karnego (1998) ${ }^{14}$ gwałty dokonywane w czasie konfliktów o charakterze narodowym, etnicznym czy religijnym, nierzadko z udziałem przedstawicieli instytucji policyjnych i wojskowych, uznawane były za „naturalne” konsekwencje tych operacji, z uwagi na fakt, że przemoc seksualna tradycyjnie definiowana była jako przynależna sferze prywatnej. Wieloletnie akcje feministyczne oraz przyjęcie konwencji CEDAW i CAHVIO ostatecznie doprowadziły do uznania tych czynów za naruszenie praw człowieka.

Z podziałem na prywatne i publiczne łączy się również kwestia niedoceniania praw ekonomicznych, społecznych i kulturowych, powodująca ograniczanie możliwości domagania się przestrzegania praw człowieka przez grupy nieuprzywilejowane. Pomimo istotnych zmian w tym zakresie, w powszechnej świadomości organizacje zajmujące się ochroną praw, jak chociażby Amnesty International, nadal kojarzone są głównie z walką przeciw takim praktykom państw, jak nieuzasadnione aresztowania czy złe traktowanie więźniów, czyli z prawami politycznymi. Według analiz feministycznych, priorytetowe traktowanie zagadnień polityczno-obywatelskich przyczynia się do wykluczania kobiet, które są bardziej narażone na przemoc w kontekście powszechnie uznawanym za prywatny. Zauważanie potrzeby ochrony przed jedynie pewnymi rodzajami przemocy prowadzi niejednokrotnie do uzasadniania genderowych, klasowych i rasowych uprzedzeń, przyczyniając się do stronniczości programu ochrony praw człowieka. Aby być pewnym, że prawa człowieka są w pełni chronione i promowane, należy zmienić zasady dotyczące jasnego formułowania tego, co faktycznie konstytuuje przestrzeganie tych praw. Zadanie to powinno być bardziej skutecznie realizowane przez współczesny feminizm globalny.

${ }^{13}$ Niamh Reilly, op. cit., s. 29-42.

14 Rzymski Statut Międzynarodowego Trybunału Karnego, cz. II, art. 7, pkt. 1.g; dostępne przez: http://prawo.uni.wroc.pl/pliki/1929 (10.12.2012). 


\section{b. Uniwersalistyczna hegemonia a relatywizm kulturowy}

Kolejnym zagadnieniem wymagającym przewartościowania jest, zdaniem Reilly, spolaryzowane zestawienie zachodniej hegemonii i kulturowego relatywizmu. Debaty na temat uniwersalności praw i ich zakorzenienia w myśli zachodniej zajmują obecnie znaczące miejsce w dyskusjach o prawach człowieka. Przeciwnicy tego podejścia wskazują na fundamentalny brak szacunku dla kulturowej różnorodności, stąd określenie „uniwersalistyczna hegemonia”. Coraz częściej do głosu dochodzą zwolennicy tezy kulturowego uprawomocniania praw. Argumentują oni, że standardy praw człowieka mogą zostać usankcjonowane jedynie w ramach stałego dialogu dotyczącego norm i wartości z przedstawicielami lokalnych kultur. Przedmiotem konsensusu muszą stać się również metody implementacji tych $\operatorname{praw}^{15}$. Z feministycznego punktu widzenia, przyjęcie stanowiska relatywizmu kulturowego możliwe byłoby tylko w sytuacji, gdyby prawa człowieka (jednostek i podgrup obecnych w ramach określonej lokalnej społeczności) były chronione przed wpływem dominującej - zazwyczaj męskiej - elity. Zwolennicy relatywizmu nie biorą jednak pod uwagę wewnątrzkulturowych nierówności i konfliktów mających niekorzystny wpływ na sytuację kobiet w takich kwestiach, jak chociażby seksualność, małżeństwo czy prokreacja.

$\mathrm{Z}$ drugiej strony, każda próba obrony uniwersalności praw z perspektywy feministycznej wymaga równie uważnej analizy ${ }^{16}$. Radykalny uniwersalizm sprzeczny jest bowiem z pluralizmem kulturowym i feministycznym rozumieniem odmienności. Ponadto, pojawiające się nierzadko w krytyce zrównanie uniwersalizacji praw z ich westernizacją wzmacnia hierarchiczny podział na Zachód i resztę świata. W miejsce tego stanowiska Reilly proponuje wielopoziomowy proces negocjacji pomiędzy podejściem uniwersalnym i partykularnym (kulturowo relatywnym); w dobie globalizacji konieczne jest bowiem stworzenie platformy współistnienia dla kulturowo specyficznego i kosmopolitycznego zaangażowania w prawa człowieka. Ważne jest również zapewnienie, by krytyka praw człowieka jako instytucji reprezentującej wyłącznie zachodnie (a więc tylko lokalne) wartości narzucane państwom niezachodnim, nie miała już uzasadnionych podstaw. By to osiągnąć, prawa powinny być permanentnie otwarte na rekonstrukcje w toku jak najszerszego dialogu dotyczącego zarówno uzgadnianych stanowisk faktycznych, jak i proponowanych norm.

${ }_{15}$ Zob.: Abdullahi Ahmed An-Na'im, Toward a Cross-Cultural Approach to Defining International Standards of Human Rights: the Meaning of Cruel, Inhuman, or Degrading Treatment or Punishment, [w:] ed. idem, Human Rights in Cross-Cultural Perspectives: A Quest for Consensus, University of Pennsylvania Press, Philadelphia 1992, s. 19-43.

${ }_{16}$ Zob.: Jack Donnelly, The Concept of Human Rights, Cornell University Press, Itaca 1989. 


\section{c. Dylemat państwocentryczności}

Kolejnym problemem napotykanym przez teoretyków praw człowieka jest niezawisłość państwowa, rozumiana jako niepodważalna zasada uznająca państwo za ostateczne źródło prawnego i politycznego autorytetu, w pełni autonomiczny podmiot, decydujący o prowadzeniu wszystkich swoich spraw. Zdaniem Reilly, siła tej zasady prowadzi do sprzeczności, wzmacnia bowiem opór państw wobec zewnętrznej odpowiedzialności. Międzynarodowa wspólnota (struktury ponadnarodowe) jest stawiana wówczas w pozycji „,bezsilnego innego" wymuszającego podporządkowywanie się i wypełnianie międzynarodowych zobowiązań, czym niezamierzenie wywołuje opór wobec aplikacji standardów praw człowieka.

Państwocentryczne podejście do praw człowieka wzmacnia także uznawanie praw politycznych i obywatelskich jako praw pierwszej wagi, choćby poprzez sam fakt, że ich naruszanie jest łatwiej rozpoznawalne. Promowanie praw społecznych i ekonomicznych wymaga bowiem praktykowania bardziej aktywnej roli państwa w zapewnieniu dostępu do korzystania z tych praw. Działania państwa obejmują wówczas chociażby konieczność sprawdzania, czy asygnowane agencje uczyniły wystarczająco dużo, by zapobiec łamaniu praw i dozorowania niepaństwowych instytucji odpowiedzialnych za ich ewentualne naruszenia. Wymagane jest na przykład efektywne wsparcie organizacji niosących pomoc ofiarom przemocy domowej, jak również sprawdzanie, czy sprawcy są odpowiednio karani.

$\mathrm{Z}$ uwagi na to, że nie wydaje się być korzystne ustanawianie jednego światowego systemu zarządzania, odrębne państwa nadal będą odgrywać kluczową rolę w procesie implementacji praw człowieka. Na mocy ratyfikowanych przez nie traktatów międzynarodowych, to państwa zobowiązane są do sporządzania raportów ewaluacyjnych dla właściwych agencji ONZ i wyjaśniania ewentualnych wątpliwości. Nieformalnie, większość międzynarodowych ciał monitorujących działania podejmowane przez poszczególne kraje korzysta jednak również z informacji pochodzących od organizacji NGO i quasi-niezależnych agencji. Aktywne uczestnictwo lokalnie ukonstytuowanych i oddolnych organizacji w przygotowywaniu raportów odgrywa więc zasadniczą rolę w kontrolowaniu rządów i organów wykonawczych. Jednakże organizacje takie często nie posiadają wystarczających środków lub są zbyt słabo rozwinięte. I tu pojawia się potrzeba zaangażowania i uczestnictwa organizacji feministycznych. Doprowadzi to, zdaniem Reilly, do wzmocnienia procesów deregulacji, podważenia państwocentrycznych praktyki w sferze praw człowieka, jak i zwiększenia społecznej aktywności obywatelskiej. Zanegowanie hegemonii państwa wspomaga dodatkowo nierozłączność praw społecznych, ekonomicznych i kulturowych w obszarze publicznym i prywatnym. 


\section{d. Uniwersalizm i zachodni imperializm}

Po atakach terrorystycznych na World Trade Center z 11 września 2001 roku wykorzystywanie retoryki praw kobiet jako praw człowieka przybrało wyjątkowe formy. Ochrona praw kobiet została wykorzystana dla uzasadnienia inwazji na Afganistan ${ }^{17}$ i Irak. Użyto jej również do podsycania moralnej paniki wobec islamu w krajach zachodnich (co skutkowało chociażny zakazem noszenia hidżabu przez muzułmańskie kobiety w miejscach publicznych we Francji). Instrumentalizowanie dyskursu praw kobiet jako praw człowieka dla legitymizacji neoliberalnej ideologii politycznej wskazuje na konieczność oporu i potrzebę wyraźniejszego promowania tych praw jako narzędzia przeciwko dominacji polityki państw.

W licznych popularnych przekazach, jak i w postkolonialnych dyskursach feministycznych, pojawia się opinia, że doktryna praw kobiet jako praw człowieka jest konstrukcją charakterystyczną dla instytucji współczesnego porządku polityczno-ekonomicznego. Postkolonialna teoretyczka, Inderpal Grewal, utrzymuje na przykład, że transnarodowy feministyczny aktywizm praw człowieka sam wpisuje się w neoimperialistyczną ideologię, z typową dla niej autorytarna postawą wobec państw nie-zachodnich ${ }^{18}$. Wyraźnym tego przykładem jest, jej zdaniem, działalność feministycznych organizacji funkcjonujących pod patronatem przedstawionej wcześniej Global Campaign. Utrzymuje ona, że aktywistki tych grup często kontynuują po prostu wcześniejszy dyskurs tzw. „globalnego siostrzeństwa” (termin wprowadzony przez Robin Morgan w 1984 roku) ${ }^{19}$ i zajmują się monitorowaniem wyłącznie problemów występujących w innych społeczeństwach (czyli poza krajami Pierwszego Ś wiata $^{20}$ ). Powołując się na Michela Foucault stwierdza, że taki aktywizm jest klasycznym przykładem „rządomyślności” (governmentality) i produkowania wiedzy przez podmioty, które uważają siebie za moralnie bardziej rozwinięte i dysponujące większą wolnością, a więc uprawnione do uzgadniania i ulepszania dobrostanu kobiet całego świata ${ }^{21}$. Uzasadniając krytykę przedsięwzięć Global Campaign, Grenwal argumentuje, że nie jest możliwe, aby agencje działające w ramach dominującego w świecie państwa

${ }_{17}$ Zob.: Ranjana Khanna, Taking a Stand for Afghanistan: Women and the Left, „Signs” 2002, vol. 28, no. 1, s. 64-65.

${ }^{18}$ Inderpal Grewal, 'Women's Rights as Human Rights': Feminist Practices, Global Feminism and Human Rights Regimes in Transnationality, „Citizenship Studies” 1999, vol. 3, issue 3, s. 337-354. Por. również: Inderpal Grewal, Transnational America: Feminisms, Diasporas, Neoliberalisms, Duke University Press, Durham (NC) 2005.

19 Robin Morgan, Sisterhood Is Global: The International Women's Movement Anthology, Doubleday, New York 1984.

${ }^{20}$ Por.: Gayatri Chakravorty Spivak, op. cit.

${ }^{21}$ Zdaniem Grewal, ten „dyskurs moralnej wyższości” jest częścią nie tylko „feminizmu globalnego" w USA, ale też w Europie. 
(przez nie też finansowane) i realizujące choćby pośrednio jego politykę, mogły być niezależne. Jak również, żeby były w stanie stawiać opór w przypadkach pojawienia się nieakceptowanych decyzji rządu oraz w należyty sposób wgłębiać się w specyfikę rozwiązywanych przez siebie problemów dotyczących osób (kobiet) w innych krajach.

Jest to poważny zarzut. Reilly odrzuca wprawdzie krytykę Grewal jako zbyt powierzchowną, gdyż opartą na stronniczo wybranych fragmentach raportów Global Campaign, jednakże zauważa, że jest ona warta uwagi ze względu na paradygmatyczny dla poststrukturalnej krytyki wobec doktryny praw kobiet charakter. Zarzut stosowania przez globalny feminizm neoimperialistycznej logiki jest, jej zdaniem, konsekwencją wielce dyskusyjnej postmodernistycznej ontologii, zgodnie z którą każda próba uniwersalizowania specyficznych przypadków prowadzi do likwidowania istniejących różnic i, jako taka, ma charakter opresyjny. Promowanie przez Global Campaign wspólnych ram odniesienia - dokonywane w oparciu o politykę „niekonfliktowego pluralizmu" - w żadnym jednak przypadku nie jest ideologią o imperialistycznych tendencjach. Wręcz przeciwnie, dzięki rozumieniu praw człowieka jako „pustych uniwersaliów”, które (w oparciu o informacje pochodzące bezpośrednio od przedstawicieli osób uprzednio pomijanych czy wykluczanych z publicznego dialogu) są następnie wypełniane szczegółową treścią, następuje relatywizacja kontekstu. Mechanizmy definiowania i ewaluacji przypadków naruszania praw człowieka określane są w toku szczegółowych negocjacji z lokalnymi przedstawicielami ${ }^{22}$.

Ten proces negocjacji nie jest jednak łatwy. Wątpliwości, jakie się tu pojawiają, dotyczą takich kwestii jak to, kim są przedstawiciele danej społeczności i jakie wartości kulturowe są przez nich reprezentowane. Tak zwane głosy organizacji grassroots mogą być równie dobrze opiniami lokalnych demagogów, zwłaszcza w społeczeństwach, w których instytucje zarządzania demokratycznego mają złą historię. Podając różne propozycje rozwiązania tego dylematu, np. pozycję Abdullaha An-Na'im²3, opowiadającego się za wzmocnieniem kulturowej legitymizacji praw człowieka poprzez ciągła interpretację tych praw w świetle lokalnych norm i wartości, sama Reilly optuje za „feministycznym komunitarianizmem” łączącym formułowane w tradycyjnej konwencji liberalnej uniwersalne prawa z projektami opracowanymi przez wspólnoty lokalne, przy wyraźnym zastrzeżeniu możliwości

${ }^{22}$ Niamh Reilly, Doing Transnational Feminism, Transforming Human Rights: the Emancipatory Possibilities Revisited, „Irish Journal of Sociology” 2011, vol. 19, issue 2, s. $60-76$.

${ }^{23}$ Abdullah An-Na'im, op. cit., s. 19. 
dalszego kwestionowania, rewizji i zmiany tych projektów w toku kolejnych negocjacji ${ }^{24}$.

Autorka przedstawia też listę warunków formułowania i interpretacji praw kobiet, tak by spełniały one emancypacyjne funkcje globalnego feminizmu $^{25}$. Jej zdaniem, konieczne jest w tym celu: rozwijanie krytycznej globalnej feministycznej świadomości podważającej oddziaływanie opresyjnych stosunków władzy, rodzących się nie tylko na poziomie lokalnym, ponadlokalnym, ale i transnarodowym; monitorowanie głównego nurtu systemu praw człowieka i podważanie hegemonicznych teorii i praktyk, które mogą prowadzić do wykluczania lub marginalizowania poszczególnych grup, jednostek czy zagadnień; zwracanie większej uwagi na intersekcjonoalność przy analizowaniu tożsamości i doświadczeń kobiet; rozwijanie strategii działań dotyczących partykularnych problemów uniemożliwiających egzekwowanie praw człowieka oraz stałe zaangażowanie feministek w dyskusje na forach globalnych i w gremiach decyzyjnych. Rozważania Niamh Reilly są, jak dotąd, najobszerniejszym i najbogatszym źródłem informacyjnym i interpretacyjnym dotyczącym praw kobiet, jakie pojawiły się w ramach współczesnej feministycznej myśli politycznej.

\section{Carol C. Gould: solidarność i troska w prawach człowieka}

Do debaty na temat globalizmu, demokracji i praw człowieka włączyła się również Carol C. Gould. Filozofka nakreśliła projekt rozszerzenia demokracji w konceptualnych ramach udoskonalonych praw człowieka w kontekście teorii krytycznej oraz współczesnych teorii feministycznych. Swoje przedsięwzięcie nazwała „interspołecznościową demokracją” (intersociative democracy), podkreślając współzależność transnarodowej (transgranicznej) solidarności ${ }^{26}$. Co ważne, autorka nie koncentruje się na interpretacji istniejącej już listy praw człowieka; zrobili to, jej zdaniem, bardzo dobrze zarówno Martha Nussbaum ${ }^{27}$, jak i aktywistki/ści praw człowieka w związku ze światowymi konferencjami i pracą w zespołach ONZ. Rozwija natomiast kwestię praw kobiet jako praw człowieka, czyli takiego interpretowania praw człowieka, aby uczynić je bardziej adekwatnymi względem doświadczenia kobiet żyjących w odmiennych systemach ekonomiczno-politycznych.

${ }^{24}$ Niamh Reilly, Cosmopolitan Feminism and Human Rights, „Hypatia: A Journal of Feminist Philosophy” Fall 2007, vol. 22, no. 4, s. 181-183.

${ }^{25}$ Ibidem.

${ }^{26}$ Carol C. Gould, Globalizing Democracy and Human Rights, Cambridge University Press, New York 2004, s. 3.

${ }^{27}$ Zob.: Martha C. Nussbaum, Sex and Social Justice, Oxford University Press, New York 1999; Martha C. Nussbaum, Women and Human Development: The Capabilities Approach, Cambridge University Press, Cambridge 2000. 


\section{a. Osobiste jest polityczne}

Za jedną z najistotniejszych kwestii w kontekście praw człowieka Carol C. Gould uznaje, podobnie jak Niamh Reilly, podział na sferę prywatną i publiczną. Podkreśla przy tym, że na przestrzeni ostatnich dekad wiele zostało w tej kwestii zmienione. Konwencje ONZ, w tym zwłaszcza CEDAW z 1979 roku oraz wiedeńska Deklaracja o eliminacji przemocy wobec kobiet z 1993 roku, podważyły ów podział, choćby poprzez stwierdzenie explicite, że dyskryminacja wobec kobiet nie może być tolerowana w żadnej sferze i że eliminowanie tej przemocy jest obowiązkiem państw ${ }^{28}$. Gould przypomina, że dokumenty te były wynikiem prowadzonej przez wiele lat feministycznej akcji pod hasłem „osobiste jest polityczne”29 i równocześnie proponuje ochronę indywidualnych wyborów poprzez wyraźne wyszczególnienie kwestii przynależących do sfery osobistej, takich jak chociażby wybór partnera seksualnego czy prawo do (nie)posiadania dzieci. Filozofka zdaje sobie bowiem sprawę ze złożoności i niebezpieczeństw, do jakich może prowadzić nadmierne upolitycznienie sfery prywatnej. W kontekście rozpatrywanej wolności wyboru pojawia się na przykład problem uprzywilejowania w niektórych społeczeństwach męskiej płci dziecka często prowadzącego do aborcji płodów dziewczynek czy pozorny wybór prostytucji jako formy utrzymania. Jedynym rozwiązaniem w tych przypadkach jest, jej zdaniem, zrównanie ekonomicznego i społecznego statusu kobiet, w tym dostępu do pracy, wynagrodzenia, edukacji, opieki zdrowotnej i antykoncepcji. Zapobieganie krzywdzącym kobiety ich własnym „wolnym wyborom” wymaga więc większych zabiegów i uwagi w sferze praw ekonomicznych i społecznych, znacznie wykraczających poza samo teoretyczne podważenie dychotomii prywatne - publiczne czy osobiste - polityczne.

\section{b. Legitymizacja praw kobiet}

Dylemat uprawomocnienia praw kobiet jako praw człowieka staje się, w opinii Gould, również problemem filozoficznym. Chodzi tu bowiem o wcześniej postawione, podstawowe pytanie, czy, uznając niektóre prawa człowieka jako specyficzne dla kobiet, a więc genderowo zróżnicowane, nie naruszamy tym samym uniwersalności praw człowieka i wynikającego z niej wymogu równego traktowania wszystkich ludzi. Odnosząc się do tej kwestii, Gould rozróżnia prawa człowieka podstawowe (np. prawo do życia, wolności, opieki lekarskiej i podstawowej edukacji) i niepodstawowe (np. prawo do płatnych wakacji). Filozofka proponuje traktowanie praw podstawowych

${ }^{28}$ Por.: Konwencja w sprawie likwidacji wszelkich form dyskryminacji kobiet, cz. I, art. 2; dostępne przez:http://www.hfhrpol.waw.pl/pliki/Konwencja_w_Sprawie_Likwidacji_Wszelkich_Form_Dyskry-minacji_Kobiet.pdf (10.12.2012).

${ }^{29}$ Carol C. Gould, op. cit., s. 147-149. 
jako niezróżnicowanych, zaś niepodstawowych jako zróżnicowanych. W tym sensie równość nie oznacza automatycznie konieczności, ani też potrzeby, takiego samego traktowania wszystkich osób. Zasada nierozłączności, określana jako niewątpliwe osiągnięcie kobiet (patrz: Reilly), zalecająca traktowanie na równi wszystkich praw, prowadzi do powyższego dylematu i powinna być ponownie poddana pod rozwagę feministek ${ }^{30}$.

\section{c. Teoria praw czlowieka a teoria troski}

Interesującym, aczkolwiek nieco kontrowersyjnym, zabiegiem dokonanym przez Carol C. Gould jest próba łączenia teorii praw człowieka z teorią troski. Teoria troski została już zaadoptowana do dziedziny stosunków międzynarodowych (głównie dzięki pracom Fiony Robinson ${ }^{31}$ ), jednak jak dotąd nie była analizowana w kontekście koncepcji praw człowieka. Tymczasem, zdaniem Gould, ich wzajemne związki są znacznie głębsze niż uważano. Jednym z głównych zarzutów wobec teorii praw jest jej rzekomo abstrakcyjny indywidualizm, któremu to zarzutowi Gould sprzeciwia się, argumentując, że bez podkreślania intersubiektywnych więzi pomiędzy ludźmi sama koncepcja praw nie miałaby sensu. Uznając człowieka jako posiadającego prawa, automatycznie uznajemy go za osobę charakteryzującą się wolnością i godnością (w kantowskim znaczeniu), co rzeczywiście stanowi abstrakcyjny i indywidualistyczny akcent praw człowieka. Dostrzegamy człowieczeństwo każdego bez względu na różnice, jednak kontekst jego uznania jest fundamentalnie intersubiektywny i społeczny. Ta głęboko społeczna koncepcja wzajemności jest, wedle Gould, integralnie wbudowana w samą ideę praw człowieka.

Nawiązując do etyki feministycznej, którą utożsamia z etyką troski, Gould stawia tezę, że jeśli ludzie nie mieliby skłonności do troski o potrzeby i dobrostan innych, zobowiązania wobec nich nie byłyby realizowane, gdyż nie istniałaby motywacja do poważnego traktowania wszelkich zobowiązań. Nieobecność troski w dotychczasowej teorii polityki wydaje się wynikać z dominacji mężczyzn w tym obszarze. Jeśli zatem feministyczne etyczki mają rację umiejscawiając troskę w centrum ludzkiego doświadczenia, można stwierdzić, że prawa człowieka są zakorzenione w trosce i zainteresowaniu, jakie odczuwamy nie tylko wobec bliskich, ale wszystkich innych osób. Konsekwencją zorientowania na troskę w prawach człowieka jest chociażby poparcie dla materialnego wspomagania innych, dostarczania opieki zdrowotnej i edukacji.

${ }^{30}$ Ibidem, s. 152-153.

${ }^{31}$ Zob.: Fiona Robinson, Globalizing Care: Ethics, Feminist Theory and International Relations, Westview Press, Boulder 1999. 
Oprócz podkreślania roli empatii w moralności, koncepcja troski i zaangażowanego działania obejmuje również pojęcie odpowiedzialności, rozumianej nie tylko w kontekście dokonanego czynu, ale przede wszystkim jako nieprzerwanego zainteresowania dobrostanem innych. Chociaż to oczywiste, że nie możemy troszczyć się o wszystkich w równym stopniu, istnieje sposób na rozszerzenie tego, co możemy nazywać podstawową troską stosowaną globalnie ${ }^{32}$. Gould proponuje przyjęcie wspólnej odpowiedzialności za podstawowe potrzeby innych; w tym sensie mówi o prawie człowieka do troski i do jej okazywania. Nie sugeruje, że należałoby dopisać takie prawo do istniejącej już listy praw. Chodzi jej raczej o podkreślenie wagi, jaką pełni troska ludzi względem siebie, co wbrew pozorom nie jest wcale tak oczywiste i wymaga systematycznego uświadamiania, podkreślania i nieustającej edukacji społeczeństwa.

\section{d. Troska czy solidarność?}

W pracy Transnational Solidarities w miejsce, czy raczej obok, koncepcji troski teoretyczka rozwija ideę solidarności jako formy transnarodowych wzajemnych interakcji w obrębie regionalnych lub globalnych ram praw człowieka. Solidarność pośredniczy bowiem pomiędzy partykularnymi relacjami na poziomie interpersonalnym, jak również na poziomie abstrakcyjnych zasad uniwersalnych ${ }^{33}$. Chodzi tu relacje, jakie można nawiązywać z oddalonymi geograficznie osobami i grupami dzięki pracy, więzom ekonomicznym czy wykorzystaniu w nowych mediach. Gould sądzi wręcz, że efektywne relacje solidarności, będąc koniecznym komponentem uznawania praw człowieka, mogą mieć wpływ na wyłonienie się bardziej demokratycznych form transnarodowych interakcji. Swoje rozumienie solidarności określa mianem „zachodzących na siebie sieci solidarności” (overlapping nets of solidarity ${ }^{34}$. O ile troska ma, w jej opinii, najpełniejsze zastosowanie w relacjach interpersonalnych, solidarność jest pojęciem bardziej adekwatnym dla grup społecznych i związków pomiędzy nimi. Ostatecznie Gould traktuje troskę i solidarność jako elementy komplementarne, które motywują nasze zaangażowanie w realizację praw człowieka.

O ile propozycje filozofki mogą rodzić zastrzeżenie co do możliwości ich uprawomocnienia (np. powszechny wymóg empatii), otwiera ona nową przestrzeń dla dyskusji w sferze etyki globalnej.

${ }^{32}$ Carol C. Gould, op. cit., s. 145-146.

33 Carol C. Gould, Transnational Solidarities, „Journal of Social Philosophy” Spring 2007, vol. 38, no. 1, s. 148-164.

34 Ibidem, s. 148. 


\section{Brook A. Ackerly: głos aktywistek}

Kompromisem pomiędzy propozycjami stricte teoretycznymi a głosami pochodzącymi od praktyków jest propozycja politolożki Brooke A. Ackerly. W książce Universal Human Rights in a World of Difference (2008), jak również w licznych artykułach, autorka postuluje krytyczną teorię i metodę afirmacji uniwersalności praw człowieka w obecnym, niezwykle złożonym i zróżnicowanym, świecie. Rozważa możliwości przełożenia norm praw człowieka na narzędzia zmian społecznych, wyjaśnia role teoretyków i aktywistów funkcjonujących w tej sferze, a także ewentualne sposoby ich współdziałania. Mówiąc o teoretyzowaniu w „partnerskich relacjach z aktywistami”, łączy te, często traktowane rozdzielane, perspektywy ${ }^{35}$. Nakreśla opartą na doświadczeniach aktywistek „immanentną teorię” (activist-informed immanent theory of universal human rights) ${ }^{36}$. Ta teoria ma wymiar etyczny, bowiem oferuje zarówno opis tego, co myślą i co robią działaczki, jak również jest propozycją, co powinny myśleć i w jaki sposób działać, by kompetentnie realizować normy praw człowieka.

W swych pracach autorka opiera się na wywiadach przeprowadzonych z przedstawicielkami NGO i lokalnymi aktywistkami w trakcie konferencji ONZ, zjazdów Światowego Forum Społecznego czy międzynarodowych spotkań promujących feministyczny dialog ${ }^{37}$. Podpisywane przez państwa członkowskie konwencje mogą się wydawać zbyt ogólne lub nierealne do przeprowadzenia, zwłaszcza przy braku zdeterminowania państw do ich przestrzegania. Rządowe i międzynarodowe organizacje wskazują na potrzebę wspierania tych regulacji, ale nie zawsze na sposoby ich realizowania. Ackerly dostrzega potrzebę sformułowania takiej teorii i metodologii, która efektywnie pokieruje aktywistami zarówno pracującymi w strukturach państwowych, jak i w organizacjach pozarządowych. Teoretyzowanie w partnerskiej współpracy z aktywistkami nie polega wyłącznie na uczeniu się od nich, by następnie, korzystając z dostarczonych informacji, proponować oparte na uogólnieniach teoretyczne rozwiązania. Niezbędne jest utrzymywanie stałej komunikacji pomiędzy międzynarodowymi adwokatkami praw człowieka a lokalnymi aktywistkami.

Ważnym zagadnieniem dla feministek jest kwestia przetwarzania dyskursu uniwersalnych praw człowieka tak, aby uwzględniał olitykę różnicy. W tym celu Ackerly, w ramach teorii immanentnej, proponuje metodę immanentnej krytyki. Jest to filozoficzna metastrategia, polegająca na rozważaniu

35 Brooke A. Ackerly, Human Rights Enjoyment in Theory and Activism, „Human Rights" 2011, no. 12, s. 221-229.

${ }^{36}$ Brooke A. Ackerly, Universal Human Rights in a World of Difference, Cambridge University Press, Cambridge 2008, s. 92-93.

37 Brooke A. Ackerly, Universal Human..., op. cit., s. 142-149. 
motywacji krytycznych ocen danego zjawiska i analizowaniu ich w świetle własnej, starannie rozpoznanej, pozycji normatywnej. Ma ona umożliwić ocenę i uzasadnienie partykularnych okoliczności i warunków, bez opierania się na transcendentalnym autorytecie praw człowieka (idealnego Dobra, Zła czy odwiecznej Natury) ${ }^{38}$.

Dla wzmocnienia połączeń pomiędzy powszechnymi prawami człowieka i wrażliwością na różnice, pomocne może być również dociekanie, jak pozornie unikalna perspektywa upośledzonych lub narażonych na niedogodności grup stwarza korzystne dla ogółu społeczeństwa rozwiązania. „Wygładzający krawędzie feminizm" (curb-cut feminizm - termin zaczerpnięty z dokumentów o prawach niepełnosprawnych w Stanach Zjednoczonych) pozwala dostrzec, jak realizowanie potrzeb partykularnej grupy może prowadzić do osiągania korzyści przez znacznie szersze grupy beneficjentów. Przykładem niech będzie dostosowanie ulic i pojazdów do potrzeb niepełnosprawnych, które umożliwia sprawne funkcjonowanie również innym użytkownikom, na przykład osobom podróżującym z wózkami lub bagażem. Uznać to można za praktyczny sposób dochodzenia do uniwersalności (powszechności) poprzez różnice (partykularyzmy) ${ }^{39}$.

Wzorując się na stanowiskach Marthy Nussbaum i Amartya Sena (twórców „podejścia możliwości”, w miejsce podejścia koncentrującego się na faktycznym funkcjonowaniu), Ackerly podkreśla, że realizacja praw zawiera się w, jak to określa, „cieszeniu się” (enjoying) prawami, samo formalne uznanie i uprawomocnienie nie jest bowiem równoznaczne z możliwością korzystania z nich. Ugruntowana empirycznie uniwersalna teoria praw człowieka jako teoria zmian, nie może być w pełni zrozumiana poprzez samą refleksję nad tym, czym są te prawa. By je rozumieć, należy uwzględnić praktyki, które promują i umożliwiają „cieszenie się” nimi. Nie można też zmieniać zakresu korzystania z praw wyłącznie poprzez uzupełnienia i aneksy. Ackerly twierdzi, że konieczny jest tu tzw. powiązany aktywizm (connected activi$\mathrm{sm})^{40}$. Zmiana działania następuje bowiem poprzez wzajemne powiązanie ról i umiejętności osób zaangażowanych w daną działalność na poziomie międzynarodowym i lokalnym, zróżnicowanym politycznie, ekonomicznie i społecznie ${ }^{41}$. Omawiana strategia działań aktywistów powinna charakte-

${ }^{38}$ Ibidem, s. 92-93.

${ }^{39}$ Ibidem, s. 35-36.

${ }^{40}$ Brooke A. Ackerly, Human Rights Enjoyment..., op. cit., s. 227.

${ }^{41}$ Przykładem może być hinduska organizacja Self-Employed Women's Association (SEWA), promująca i zrzeszająca kobiety, które w jej ramach zapewnią sobie samozatrudnienie bez angażowania instytucji zewnętrznych. Por.: Sidney Schuler, Syed Hashemi, Harshida Pandit, Beyond Credit: SEWA's Approach to Women's Empowerment and Influence on Women's Reproductive Lives in Urban India; dostępne przez: http://www.sewaresearch. org/pdf/researches/beyond_credit.pdf (10.05.2013). 
ryzować się: stosowaniem analitycznej intersekcjonalności; skupianiem się na wąskim odcinku przy równoczesnym braniu pod uwagę szerokiego kontekstu; ukazywaniem kompleksowości mechanizmu władzy stanowiącej przeszkody w realizacji prawa; oraz wzmacnianiem i wspieraniem zaangażowanych stron, włączając w to społeczność ochotników ${ }^{42}$.

Dodatkowy wkład Brook A. Ackerly do analiz funkcjonowania praw człowieka stanowi propozycja metodologii empirycznych studiów nad tymi prawami. Badaczka proponuje nowy (niejako od wewnątrz) sposób pomiaru dostępności praw połączony z analizą oceny korzystania z nich przy uwzględnieniu takich wskaźników, jak: wiek, płeć, sytuacja społeczno-ekonomiczna. Dotychczasowe badania oceniają skuteczność funkcjonowania praw człowieka z perspektywy nadawanych uprawnień oraz łamania praw, a więc ocenie podlegają standardy, a nie ich stosowanie. Ackerly wskazuje na potrzebę sprawdzania, jak jednostki postrzegają swoje swobody i jak rozumieja koncepcję praw człowieka w kontekście swoich codziennych potrzeb. Zaproponowane podejście pozwala dowiedzieć się, jak realizacja praw jest postrzegana w zależności od sytuacji i regionu geograficznego (np. na obszarach zagrożonych klęskami naturalnymi, wojnami, w połączeniu z sytuacją ekonomiczną). Sądzi, że badania wymagają zadawania innego rodzaju pytań, tzn. nie dotyczących wprost doświadczeń indagowanej osoby, ale raczej posiadanych przez nie informacji o innych (o przemocy domowej, rasizmie itp.). Nie przekraczając granic prywatności, możemy w ten sposób otrzymać więcej szczegółowych informacji ${ }^{43}$.

Projekt Ackerly nie podważa istniejących metod badania przestrzegania praw człowieka, ale wzbogaca je o wiedzę na temat poczucia bezpieczeństwa różnych grup (niepełnosprawnych, imigrantów, kobiet, mniejszości etnicznych, seksualnych i rasowych), tak w poszczególnych krajach, jak i w skali globalnej. Służyć też może lepszej ocenie lokalnych zmian i ułatwiać sterowanie nimi. Autorka szczególnie dużo uwagi poświęca problematyce metodologii pracy feministycznych teoretyczek polityki i filozofek praw człowieka. By zminimalizować błędy wynikające z niebezpieczeństwa stronniczości, wskazuje na konieczność zachowywania refleksyjnego dystansu i wzmożonej ostrożności wobec własnych doświadczeń i społeczno-kulturowo-ekonomicznego usytuowania. Stosowanie określonych ram teoretycznych wymaga świadomości, że mogą one pomijać niektóre głosy i odmienne perspektywy.

${ }^{42}$ Brooke A. Ackerly, Human Rights Enjoyment..., op. cit., s. 228-239.

43 Autorka przeprowadziła takie badania w latach 2006-2007 na grupie 34 tys. osób w 22 krajach (obie Ameryki). 


\section{Zakończenie}

Transnarodowe projekty feministyczne dotyczące wspomagania praw człowieka łączą krytykę dominujących modeli i podejścia oddolne, pochodzące od grup bezpośrednio zaangażowanych w ich realizację, w taki sposób, by spełniały swą emancypacyjną funkcję. Feministyczne teoretyczki coraz częściej sięgają w swych badaniach wprost do lokalnych aktywistek, włączając partykularne potrzeby określonych społeczności do ogólnych projektów bez zatracania specyfiki poszczególnych przypadków. Uniwersalizm praw człowieka i jego ugruntowanie w doktrynie liberalnej wymaga korekty. Idealistyczne podejście do transformatywnych możliwości praw człowieka - w oparciu o sam fakt ich istnienia - podważane jest przez abstrakcyjność prawnych ustaleń, które nawet w sprzyjających okolicznościach są w stanie dostarczyć jedynie powierzchownej pomocy kobietom w różnych częściach globu. Krytyka abstrakcyjnego uniwersalizmu otwiera również okazję do przyjrzenia się wysoce dyskusyjnym nacjonalistycznym i relatywistycznym orientacjom, które w ocenie feministek, rzadko bywają korzystne dla samych kobiet w ich lokalnych społecznościach. Jak zauważają Mary Jane Alexander i Chandra Talpade Mohanty, „lokalna feministyczna praxis jest konieczna, lecz konieczne jest również rozumienie lokalności w relacji z większymi, ponadnarodowymi procesami" ${ }^{44}$. Podejmowane aktualnie szeroko zakrojone feministyczne badania są obiecującą perspektywą dla zmian w tradycyjnie rozumianej perspektywie praw człowieka.

\section{BIBLIOGRAFIA}

Ackerly Brooke A., Human Rights Enjoyment in Theory and Activism, „Human Rights” 2011, no. 12.

Ackerly Brooke A., Universal Human Rights in a World of Difference, Cambridge University Press, Cambridge 2008.

Action Plan, Council of Europe, 17 May 2005; dostępne przez: http://www.coe.int/t/dcr/ summit/20050517_plan_action_pl.asp (01.05.2013).

Alexander Mary Jane, Chandra Talpade Mohanty, Feminist Genealogies, Colonial Legacies, Democratic Futures, Routledge, New York 1997.

An-Na'im Abdullahi Ahmed, Toward a Cross-Cultural Approach to Defining International Standards of Human Rights: the Meaning of Cruel, Inhuman, or Degrading Treatment or Punishment, [w:] ed. idem, Human Rights in Cross-Cultural Perspectives: A Quest for Consensus, University of Pennsylvania Press, Philadelphia 1992.

Bunch Charlotte, Global Campaign for Women's Human Rights: Where Next After Vienna, „St. John's Law Review” 1995, vol. 69, issue 1, no. 1-2.

${ }^{44}$ Mary Jane Alexander, Chandra Talpade Mohanty, Feminist Genealogies, Colonial Legacies, Democratic Futures, Routledge, New York 1997, s. xix. 
Bunch Charlotte, Women's Human Rights: From Slogan to Global Agenda; dostępne przez: http://womensenews.org/story/books/120309/womens-human-rights-slogan-global-agenda (01.05.2013).

Connor Jane, Optional Protocol to the Convention on the Elimination of All Forms of Discrimination against Women; dostępne przez: http://untreaty.un.org/cod/avl/ha/ opceafdw/opceafdw.html (03.05 2013).

Council of Europe Convention on Preventing and Combating Violence against Women and Domestic Violence; dostępne przez: http://conventions.coe.int/Treaty/Commun/ ChercheSig.asp?NT=210\&CM=1\&DF=\&CL=ENG (03.05.2013).

Declaration on the Right to Development, dostępne przez: http://www.un.org/documents/ ga/res/41/a41r128.htm (03.05.2013).

Deklaracja o eliminacji przemocy wobec kobiet; dostępne przez: http://www.bezuprzedzen. org/doc/3cdeklPrzeciwPrzem.pdf (01.05 2013).

Donnelly Jack, The Concept of Human Rights, Cornell University Press, Itaca 1989.

Gould Carol C., Globalizing Democracy and Human Rights, Cambridge University Press, New York 2004.

Gould Carol C., Transnational Solidarities, „Journal of Social Philosophy” Spring 2007, vol. 38 , no. 1 .

Grewal Inderpal, 'Women’s Rights as Human Rights': Feminist Practices, Global Feminism and Human Rights Regimes in Transnationality, „Citizenship Studies” 1999, vol. 3, issue 3.

Grewal Inderpal, Transnational America: Feminisms, Diasporas, Neoliberalisms, Duke University Press, Durham (NC) 2005.

Khanna Ranjana, Taking a Stand for Afghanistan: Women and the Left, „Signs” 2002, vol. 28 , no. 1 .

Konwencja w sprawie likwidacji wszelkich form dyskryminacji kobiet, cz. I, art. 2; dostępne przez:http://www.hfhrpol.waw.pl/pliki/Konwencja_w_Sprawie_Likwidacji_Wszelkich_Form_Dyskry-minacji_Kobiet.pdf (10.12.2012).

Morgan Robin, Sisterhood Is Global: The International Women's Movement Anthology, Doubleday, New York 1984.

Narayan Uma, Essence of Culture and a Sense of History: A Feminist Critique of Cultural Essentialism, [w:] eds. Uma Narayan, Sandra Harding, Decentering the Center: Philosophy for Multicultural, Postcolonial and Feminist World, Indiana University Press, Bloomington 2000.

Nussbaum Martha C., Sex and Social Justice, Oxford University Press, New York 1999.

Nussbaum Martha C., Women and Human Development: The Capabilities Approach, Cambridge University Press, Cambridge 2000.

Reilly Niamh, Cosmopolitan Feminism and Human Rights, „Hypatia: A Journal of Feminist Philosophy" Fall 2007, vol. 22, no. 4.

Reilly Niamh, Doing Transnational Feminism, Transforming Human Rights: the Emancipatory Possibilities Revisited, „Irish Journal of Sociology” 2011, vol. 19, issue 2.

Reilly Niamh, Women's Human Rights: Seeking Gender Justice in a Globalizing Age, Polity Press, Cambridge 2009.

Robinson Fiona, Globalizing Care: Ethics, Feminist Theory and International Relations, Westview Press, Boulder 1999.

Rzymski Statut Międzynarodowego Trybunału Karnego, cz. II, art. 7, pkt. 1.g; dostępne przez: http://prawo.uni.wroc.pl/pliki/1929 (10.12.2012). 
Schuler Sidney, Syed Hashemi, Harshida Pandit, Beyond Credit: SEWA's Approach to Women's Empowerment and Influence on Women's Reproductive Lives in Urban India; dostępne przez: http://www.sewaresearch.org/pdf/researches/beyond_credit. pdf (10.05.2013).

Spivak Gayatri Ch., Can the Subaltern Speak?, [w:] eds. Cary Nelson, Lawrence Grossberg, Marxism and the Interpretation of Culture, University of Illinois Press, Urbana (IL) 1988.

Talpade Mohanty Chandra, Under Western Eyes Feminist Scholarship and Colonial Discourses, „Feminist Review” 1988, no. 30. 